\title{
Hubungan antara Konformitas Teman Sebaya dan Asertivitas dengan Perilaku Merokok pada Siswa di SMPN 2 Sleman
}

\author{
Eka Aryani \\ Program Studi Bimbingan dan Konseling, Fakultas Keguruan dan Ilmu Pendidikan, \\ Universitas Mercu Buana Yogyakarta \\ eka@mercubuana-yogya.ac.id
}

\begin{abstract}
Abstrak
Tujuan penelitian ini untuk mengetahui hubungan antara konformitas teman sebaya dan asertivitas dengan perilaku merokok di SMP N 2 Sleman. Metode penelitian menggunakan pendekatan korelasional. Subjek penelitian berjumlah 247 siswa SMP N 2 Sleman. Instrumen penelitian dengan skala konformitas teman sebaya (35 item dan $\alpha=0,879$ ), skala asertivitas ( 45 item dan $\alpha=0,890$ ), dan skala perilaku merokok (41 item dan $\alpha=0,891)$. Uji hipotesis dengan rumus product moment dan ANOVA yang sebelumnya diawali dengan uji normalitas $(0,125,0,462$, dan $0,164>0,05)$, uji linearitas $(0,176$ dan $0,817>0,05)$. Hasil penelitian korelasi ganda menunjukkan nilai $F_{\text {hitung }}(76,677)>F_{\text {tabel }}(3,04)$. Artinya, ada hubungan yang signifikan antara konformitas teman sebaya dan asertivitas dengan perilaku merokok. Nilai tersebut didukung dengan nilai koefisien determinan sebesar 0,386, artinya besarnya sumbangan efektif yang diberikan variabel konformitas teman sebaya dan variabel asertivitas terhadap perilaku merokok adalah sebesar $38,6 \%$, sedangkan sisanya $61,4 \%$ dipengaruhi oleh faktor lain.
\end{abstract}

Kata Kunci: Konformitas Teman Sebaya; Asertivitas; Perilaku Merokok.

\section{PENDAHULUAN}

Masa remaja merupakan masa tumbuh untuk mencapai kematangan fisik, mental, sosial, dan emosional (Piaget, dalam Hurlock, 1991: 206). Dalam perkembangannya, remaja mengalami beberapa fase diantaranya fase mencari jati diri (Piaget, dalam Hurlock, 1991: 207). Pada fase ini, remaja tidak termasuk golongan anak-anak, tetapi belum juga dapat diterima sepenuhnya sebagai golongan orang dewasa. Upaya-upaya untuk menemukan jati diri tidak semua berjalan sesuai dengan harapan orang tua maupun masyarakat karena remaja mengalami ketidaksesuaian antara perkembangan psikis dan sosialnya (Piaget, dalam Hurlock, 1991: 207).

Individu tumbuh dan berkembang dalam lingkungan keluarga, bahkan sangat tergantung pada orang tua. Ketika tumbuh menjadi remaja, individu semakin luas 
pergaulannya dengan lingkungan di luar keluarganya, terutama teman sebayanya. Remaja mulai menjauh dari pengaruh orang tua dan lebih dekat dengan teman sebaya (Santrock, 2003: 523). Remaja cenderung lebih memilih teman sebaya karena teman sebaya mampu memberikan umpan balik mengenai perilaku yang dimunculkan oleh remaja dalam kelompok, sehingga kecenderungan mereka untuk berperilaku sama dengan apa yang teman mereka lakukan mudah saja terjadi. Hal tersebut yang dinamakan dengan konformitas, yaitu melakukan perilaku yang sama dengan orang lain (Sarwono, 1999: 182).

Konformitas terhadap teman sebaya pada remaja dapat menjadi positif atau negatif (Pearl, Bryan \& Herzog, 1990: 47). Hubungan dengan teman sebaya yang saling mendukung dalam hal kebaikan akan berdampak positif. Tetapi apabila teman sebaya cenderung mengajak pada hal-hal yang maladaptif, maka akan berdampak negatif kecuali remaja tersebut memiliki sikap asertif yang tinggi. Sikap asertif dapat mencegah remaja ikut serta dalam konformitas negatif karena remaja mampu menolak dengan tegas. Asertivitas diperlukan agar remaja dapat menyesuaikan diri, baik dalam konformitas positif maupun konformitas negatif.

Konformitas positif pada kelompok teman sebaya dapat diamati pada kelompok belajar yang banyak berdiskusi mengenai pelajaran dan kegiatan ekstra kurikuler sesuai dengan bakat dan minat masing-masing. Konformitas positif memberikan dampak yang positif pula bagi remaja. Remaja akan lebih semangat dalam melakukan aktivitas karena dilakukan bersama teman-temannya. Bahkan di dalam konformitas positif seringkali diikuti dengan keinginan untuk menjadi lebih baik dari teman-temannya, sehingga dapat meningkatkan motivasi pada remaja untuk bersaing dalam berprestasi.

Konformitas negatif seringkali menjadi sorotan karena memberikan dampak negatif pada remaja. Hal ini dapat dilihat dari perilaku remaja suka tawuran, melakukan pemerasan, kebut-kebutan, pencurian, mabuk-mabukkan, mengkonsumsi narkoba dan merokok, serta berbagai bentuk perilaku yang dipandang orang dewasa sebagai perilaku maladaptif. Hal tersebut tentunya berdampak negatif, baik bagi remaja maupun lingkungan sekitarnya. Remaja ikut serta dalam konformitas negatif karena umumnya remaja takut ditolak atau diabaikan oleh teman sebayanya sehingga dapat menyebabkan munculnya perasaan kesepian atau permusuhan.

Salah satu tugas perkembangan pada remaja adalah dapat mencapai perilaku sosial yang bertanggungjawab (Havighurst dalam Hurlock, 1991: 10). Remaja diharapkan dapat memenuhi tanggungjawab sebagai orang dewasa. Namun karena belum memiliki pengalaman sebagai orang dewasa, remaja sering mengalami kegagalan. Hal ini dapat menimbulkan masalah dalam bentuk frustasi dan konflik (Rita Eka dkk, 2008: 127). Sebagian remaja yang mengalami frustasi dan konflik akan mengkompensasikannya dalam konformitas negatif.

Dari berbagai perilaku yang muncul dalam konformitas negatif peneliti mengangkat perilaku merokok sebagai salah satu masalah yang serius dan belum dapat dicegah. Fenomena merokok di Indonesia memang sudah sangat memprihatinkan, bahkan ironisnya rokok juga dinikmati oleh anak usia sekolah. Berdasarkan data yang diperoleh dari Yayasan 
Lembaga Konsumen Indonesia (YLKI), diketahui bahwa pada tahun 1995 terdapat 1.439.837 remaja perokok di Indonesia dan mengalami peningkatan secara pesat, sehingga pada tahun 2007 jumlahnya mencapai 4.227.601 orang (Anna, 2010). Hal tersebut menunjukkan bahwa konsumsi rokok pada usia remaja semakin tahun sudah semakin menjadi budaya.

Remaja pecandu rokok merasa bahwa merokok merupakan hal yang menyenangkan, sehingga perilaku merokok semakin meningkat dan menyebabkan remaja menjadi obsesif terhadap rokok (Komalasari \& Helmi, 2000). Setelah remaja mengalami ketergantungan, kebutuhan merokok pun meningkat dan bisa saja akibat desakan terhadap merokok justru mendorong remaja akhirnya mengambil langkah yang salah. Tak jarang uang jajan remaja yang masih pelajar hanya habis untuk membeli rokok daripada untuk membeli buku-buku pelajaran dan bacaan. Apabila hal ini terus berlanjut dan terus meningkat pesat maka Indonesia dapat dikategorikan sebagai negara budak rokok.

Hasil riset Lembaga Menanggulangi Masalah Merokok (Republika, 1998, dalam Komalasari \& Helmi, 2000) menunjukkan bahwa anak-anak di Indonesia sudah ada yang mulai merokok pada usia 9 tahun. Selain itu, data pada tahun 2003 menunjukkan bahwa total perokok aktif di Indonesia sudah mencapai $70 \%$ pada total jumlah penduduk sebesar 141,44 juta orang dan sekitar 13,2 \% adalah remaja berusia 15-19 tahun. Data WHO juga semakin mempertegas bahwa dari seluruh jumlah perokok yang ada di dunia sebanyak $30 \%$ nya adalah kaum remaja (Republika, 1998, dalam Komalasari \& Helmi, 2000). Data tersebut menyimpulkan bahwa perilaku merokok dimulai pada saat masa anak-anak dan masa remaja.

Data tersebut di atas didukung dengan hasil angket need assessment peneliti pada tanggal 2 November 2016 mengenai perilaku merokok pada siswa-siswi kelas VIII F SMP N 2 Sleman yang berjumlah 36 siswa. Data menyebutkan bahwa siswa yang pernah atau bahkan menjadi perokok sebesar 44,44\% yaitu 15 siswa laki-laki dan 1 siswa perempuan dari 36 siswa. Apabila dilihat dari jumlah siswa laki-laki saja (16 anak), maka persentase perilaku merokok sebesar 93,75\%. Hal tersebut menunjukkan tingginya perilaku merokok yang dilakukan oleh pelajar. Dari 16 siswa laki-laki hanya terdapat 1 siswa yang tidak pernah merokok dengan alasan karena ia ingin menjadi atlet lari sehingga ia perlu menjaga kesehatan tubuhnya. Dari 16 anak tersebut terdapat 43,75\% yang biasanya menghisap rokok 2-3 batang rokok setiap harinya.

Hasil wawancara peneliti dengan siswa pada waktu yang sama menunjukkan bahwa sebagian besar siswa yang merokok disebabkan karena ajakan teman. Hasil wawancara menunjukkan bahwa adanya pengaruh konformitas teman sebaya yang tinggi terhadap perilaku merokok pada anak usia sekolah. Hal ini sejalan dengan penelitian yang dilakukan oleh Biglan, Duncan, Any, dan Smolkowski (dalam Santrock, 2003: 513) yang menemukan bahwa perilaku merokok pada remaja merupakan ekspresi dari tingginya sikap konformitas remaja agar diterima oleh kelompok sebayanya.

Remaja cenderung ikut dan tidak dapat bersikap asertif pada ajakan teman-temannya untuk merokok disebabkan karena takut ditinggalkan oleh teman-temannya. Ada perasaan 
kesepian dan takut dianggap tidak kompak jika tidak mengikuti teman sebaya. Remaja yang bersikap asertif akan mampu menolak sesuatu yang tidak sesuai dengan dirinya meskipun ada tekanan kelompok teman sebayanya. Namun apabila remaja tidak dapat bersikap asertif maka remaja akan mentaati dan mengikuti tekanan sosial untuk berperilaku sama seperti yang dilakukan temannya. Remaja laki-laki seringkali dianggap "banci" dan "pengecut" apabila dirinya tidak merokok sehingga remaja cenderung mengikuti (conform) kelompok teman sebayanya (Komalasari \& Helmi, 2000).

Banyak anak usia sekolah dengan bangga memamerkan kepulan asap rokok yang konon menjadi identitas kegagahannya. Bahaya merokok tidak pernah terpikirkan oleh para remaja tersebut. Remaja perokok hanya mengejar gengsi pergaulan hidup sesama teman. Supaya diterima dalam kelompok, anak-anak belasan tahun sering merokok karena temantemannya juga merokok (Marvyn \& Shryock, 2001: 296). Kemudian bisa saja mereka terkena sindrom "kecanduan" terhadap barang negatif yang memiliki bahan adiktif dan nikotin yang sangat tinggi tersebut (Komalasari \& Helmi, 2000). Fenomena merokok di kalangan pelajar ini mengindikasikan lemahnya kesadaran diri pelajar sebagai tulang punggung bangsa Indonesia.

Seorang remaja terkadang mengkonsumsi rokok karena pengaruh teman sebaya yang merokok (Bronffenbrenner dalam Santrock, 2003). Menurut survei yang pernah dilakukan oleh Yayasan Jantung Indonesia, 70\% anak usia 10-16 tahun menjadi perokok karena dipengaruhi oleh temannya (shvoong.com, 2012). Berarti terungkap bahwa pengaruh teman sebaya yang di dalamnya terdapat tekanan sosial merupakan pemicu kuat timbulnya perilaku merokok remaja. Sejalan dengan pendapat McCool, et. al (2003: 6) bahwa pengaruh teman sebaya merupakan prediktor yang lebih kuat daripada faktor lainnya terhadap intensi merokok remaja. Pengaruh teman sebaya dalam hal ini berupa tekanan yang diterima dari teman sebaya untuk merokok mendorong remaja berperilaku sama dengan temannya.

Penelitian tentang hubungan perilaku merokok dengan variabel-variabel lain sudah banyak dilakukan. R. Kintoko Rochadi (2004) menyebutkan terdapat hubungan yang positif dan signifikan antara konformitas teman sebaya dengan perilaku merokok. Penelitian lain juga menyebutkan di samping aspek konformitas, perilaku merokok juga dipengaruhi oleh terapan iklan produk rokok di televisi (Nurul Fatimah, 2010) dan konsep diri perokok yang rendah (Meizha Resti Cahyani, 2012). Penelitian tersebut menyimpulkan bahwa umumnya individu mengkonsumsi rokok karena conform terhadap teman sebayanya. Tingginya konformitas pada remaja merokok disebabkan karena lemahnya asertivitas individu tersebut. Hasil penelitian tentang asertivitas juga menunjukkan adanya hubungan negatif yang signifikan antara powerful others health locus of control dan perilaku asertif pada remaja yang merokok (Yulita Mandasari, 2011).

Bertolak belakang dengan penelitian-penelitian tersebut di atas, Dita Liajayanti dan Benny Herlena (2007) mengungkapkan bahwa tidak ada korelasi positif antara konformitas dengan perilaku merokok pada mahasiswi Universitas Islam Indonesia. Tidak adanya hubungan antara konformitas dengan perilaku merokok bisa dipengaruhi faktor lainnya 
yang tidak diteliti dalam penelitian tersebut, seperti: tingkat stress, self eficacy, kepercayaan diri, atau karena subjeknya adalah perokok perempuan pada usia remaja akhir.

Setelah melakukan pengamatan dan melihat hasil-hasil penelitian yang dilakukan oleh peneliti-peneliti sebelumnya, peneliti tertarik untuk meneliti lebih lanjut mengenai "Hubungan Antara Konformitas Teman Sebaya dan Asertivitas dengan Perilaku Merokok pada Siswa di SMP". Hal ini dikarenakan kecenderungan merokok pada pelajar usia remaja di Indonesia dianggap sebagai hal yang tidak wajar serta bertentangan dengan identitas mereka sebagai seorang yang sedang dalam proses menuntut ilmu dan belajar. Apalagi mereka belum mampu untuk menghasilkan uang sendiri tetapi kenyataan yang terjadi saat ini justru semakin banyak pelajar usia remaja yang tertarik untuk mencoba-coba merokok.

\section{METODE PENELITIAN}

Penelitian ini menggunakan pendekatan kuantitatif dengan jenis penelitian korelasional yang bertujuan untuk mengetahui ada tidaknya hubungan antara konformitas teman sebaya dan asertivitas dengan perilaku merokok di SMP N 2 Sleman.Tempat penelitian dilakukan di SMP N 2 Sleman dengan pertimbangan bahwa hasil wawancara peneliti dengan siswa SMP N 2 Sleman menunjukkan bahwa sebagian besar siswa yang merokok disebabkan karena ajakan teman (pengaruh konformitas teman sebaya). Waktu penelitian dilaksanakan pada bulan April - Mei 2017. Subjek penelitian ini adalah siswa kelas VII, VIII, dan IX SMP N 2 Sleman yang berjumlah 247 siswa yang diambil melalui tenknik proportional random sampling.

Pengumpulan data dilakukan dengan skala konformitas teman sebaya, skala asertivitas dan skala perilaku merokok yang dikembangkan dengan mengadaptasi skala model Likert. Penentuan nilai mengacu pada distribusi respon responden. Skor yang digunakan antara 1-4 dengan pilihan jawaban yaitu sangat setuju (SS), Setuju (S), tidak setuju (TS), dan sangat tidak setuju (STS). Pilihan jawaban meniadakan pilihan netral untuk mengurangi respon bias responden. Item terdiri dari pernyataan mendukung (favourable statement) dan pernyataan tidak mendukung (unfavourabel statement).

Uji coba instrumen dilakukan pada siswa SMP N 2 Sleman yang berjumlah 30 siswa. Hasil yang didapatkan untuk skala konformitas teman sebaya 35 item valid dan koefisien alpha 0,879, skala asertivitas 45 item valid dan koefisien alpha 0,890, sedangkan skala perilaku merokok 41 item valid dan koefisien alpha 0,891 .

Teknik analisis data menggunakan teknik analisis deskriptif statistik dan uji hipotesis menggunakan uji korelasi Product Moment untuk uji korelasi sederhana dan perhitungan ANOVA untuk korelasi ganda yang dihitung dengan bantuan SPSS. 13. Uji persyaratan yang dilakukan sebelum uji hipotesis yaitu dengan uji normalitas, uji linearitas dan uji multikolinearitas. Hasil uji normalitas pada skala konformitas teman sebaya 0,125 ( $p>0,05)$, skala asertivitas 0,462 ( $p>0,05)$, dan skala perilaku merokok $0,164(p>0,05)$ maka dinyatakan data berdistribusi normal. Hasil uji linearitas konformitas teman sebaya dengan perilaku merokok $0,176(\mathrm{p}>0,05)$ dan asertivitas dengan perilaku merokok 0,817 
( $\mathrm{p}>0,05)$ maka data dinyatakan linear. Hasil uji multikolinearitas konformitas teman sebaya dan asertivitas $-0,292(\mathrm{p}<0,800)$, maka tidak terjadi multikolinearitas.

\section{PEMBAHASAN}

Bagian ini menyampaikan dua hal utama, yaitu (1) temuan penelitian berdasarkan hasil pengolahan dan analisis data dengan berbagai kemungkinan bentuknya sesuai dengan rumusan masalah; (2) pembahasan temuan penelitian untuk menjawab pertanyaan penelitian yang telah dirumuskan sebelumnya. Pada bagian ini pula dapat menyajikan temuan dalam bentuk grafik, tabel, gambar, dll., yang perlu dilakukan adalah menyertai tampilan tersebut dengan ringkasan penjelasan sehingga temuan tersebut menjadi lebih bermakna. Penjelasan yang dibuat sesuai dengan kondisi data apa adanya, tidak mengurangi dan melebih-lebihkan.

Hasil analisis deskriptif menunjukkan konformitas teman sebaya dalam kategori sedang dengan persentase $87,04 \%$. Konformitas teman sebaya dalam kategori sedang menunjukkan bahwa sebagian besar siswa SMP N 2 Sleman cukup memiliki nilai kekompakkan dan keseragaman untuk menyesuaikan persepsi, opini serta perilaku agar sama dengan kelompoknya. Berdasarkan hasil pengamatan peneliti di lapangan dapat dilihat bahwa hal ini dipengaruhi oleh tidak terlihat adanya pengelompokkan (genk) pada siswa sehingga siswa dapat membaur dan menjadi dirinya sendiri walaupun terkadang masih tergantung pada teman sebayanya. Hal ini sesuai dengan teori yang menjelaskan bahwa masa remaja sebagai masa mencari identitas (Hurlock, 1991: 208), sehingga remaja lebih cenderung untuk menunjukkan siapa dirinya dan bagaimana orang lain menerima dirinya. Pembentukan identitas tersebut dipengaruhi oleh perubahan fisik, psikologis serta lingkungan remaja.

Hasil analisis deskriptif menunjukkan asertivitas dalam kategori sedang dengan persentase $63,16 \%$. Asertivitas dalam kategori sedang menunjukkan sebagaian besar siswa SMP N 2 Sleman cukup memiliki kemampuan untuk mengkomunikasikan dan mengekspresikan apa yang sesungguhnya diinginkan, dirasakan, dan dipikirkan kepada orang lain dengan jujur dan nyaman. Berdasarkan hasil pengamatan peneliti di lapangan dapat dilihat bahwa hal ini dipengaruhi oleh karakteristik siswa yang cenderung tegas dan percaya diri. Hal ini sesuai dengan teori yang menjelaskan bahwa masa remaja awal (11-14 tahun) memiliki karakteristik yaitu lebih dekat dengan teman sebaya tetapi juga merasa ingin bebas dan lebih banyak memperhatikan keadaan dirinya (Marcia, dalam Sprinthall \& Collins, 2002).

Perilaku merokok dalam kategori rendah dengan persentase 65,18\%. Perilaku merokok termasuk kategori rendah karena siswa cenderung memiliki tingkat ketergantungan terhadap rokok yang rendah atau bahkan sebagian besar tidak memiliki kebiasaan menghisap rokok secara berulang-ulang sehingga menimbulkan kecanduan. Sebagian besar siswa SMP N 2 Sleman memiliki kesadaran diri sebagai seorang pelajar dalam berperilaku, walaupun sebagian kecil siswa memiliki kecenderungan perilaku merokok yang tinggi. Berdasarkan hasil pengamatan peneliti di lapangan dapat dilihat 
bahwa hal ini dipengaruhi oleh tata tertib sekolah yang cukup disiplin serta didukung oleh peran guru, pada khususnya guru pembimbing yang bertanggungjawab dalam membimbing siswa-siswanya. Hal ini sesuai dengan teori yang menjelaskan bahwa perilaku merokok dipengaruhi oleh pengaruh lingkungan, diantaranya adalah situasi sosial yang memungkinkan dapat mempengaruhi kebiasaan merokok (Alamsyah, 2009: 47) dan lingkungan bebas rokok atau bukan (Aditama, 1997).

Hasil uji hipotesis pertama menunjukkan bahwa ada hubungan yang positif dan signifikan antara konformitas teman sebaya dengan perilaku merokok. Artinya, semakin tinggi konformitas teman sebaya, maka semakin tinggi pula perilaku merokoknya, begitu pula sebaliknya. Adanya hubungan antara konformitas teman sebaya dengan perilaku merokok ini sesuai dengan pendapat dari Oskamp (dalam Minarsih, 2012) yaitu keinginan untuk ikut serta dan sama (conform) dengan teman sebaya serta keinginan untuk diterima, dianggap dan mampu menjadi bagian dari anggota kelompok membuat seorang remaja akan mengikuti perilaku teman sebayanya untuk merokok. Sebagian besar remaja memiliki tujuan konformitas untuk diterima di dalam kelompoknya, serta menghindari sanksi kelompok sehingga apabila remaja memiliki konformitas teman sebaya yang tinggi maka remaja akan melakukan apa yang dilakukan oleh teman sebayanya, termasuk perilaku merokok.

Hasil uji hipotesis kedua menunjukkan bahwa adanya hubungan yang negatif dan signifikan antara asertivitas dengan perilaku merokok. Artinya, semakin tinggi asertivitas, maka semakin rendah perilaku merokok, begitu pula sebaliknya. Adanya hubungan antara asertivitas dengan perilaku merokok ini sesuai dengan pendapat Smet (1994) yang mengemukakan bahwa remaja seringkali menganggap merokok sebagai lambang pergaulannya sehingga akan memunculkan rasa gengsi apabila tidak merokok. Rasa gengsi tersebut disertai ketidakmampuan bersikap asertif untuk menolak tuntutan merokok dalam pergaulan remaja sehingga remaja tidak percaya diri dan memberikan kesempatan pada orang lain membuat keputusan untuk dirinya. Oleh karena itu, remaja yang tidak asertif dapat menimbulkan kecenderungan perilaku merokok.

Hasil uji hipotesis ketiga menunjukkan bahwa adanya hubungan yang signifikan antara konformitas teman sebaya dan asertivitas dengan perilaku merokok. Artinya, apabila konformitas teman sebaya tinggi dan asertivitas rendah maka perilaku merokoknya cenderung tinggi, begitu pula sebaliknya. Perilaku merokok dapat dipengaruhi oleh faktor personal (untuk relaksasi, mengurangi kecemasan, gengsi atau asertivitas rendah dan pengetahuan mengenai rokok) dan faktor lingkungan (orang tua, teman sebaya, saudara, media iklan, dan budaya tertentu). Perilaku merokok pada penelitian ini dipengaruhi oleh faktor personal yaitu asertivitas yang rendah dan faktor lingkungan yaitu teman sebaya. Hal ini didukung oleh pendapat Alamsyah (2009: 47) bahwa salah satu faktor personal perilaku merokok adalah alasan psikologis yaitu perasaan gengsi dengan berperilaku merokok sehingga tidak dapat bersikap asertif, serta faktor lingkungan yaitu pengaruh teman sebaya yang mendorong seseorang memiliki obsesi untuk merokok. 
Remaja perokok hanya mengejar gengsi pergaulan di dalam kelompok teman sebayanya, maka remaja memiliki kebiasaan merokok agar remaja dapat diterima teman sebayanya. Remaja ikut serta (conform) dan tidak dapat bersikap asertif sehingga remaja akan mentaati dan mengikuti teman sebayanya untuk merokok. Hasil penelitian ini menunjukkan bahwa siswa SMP N 2 Sleman yang memiliki konformitas teman sebaya dan asertivitas kategori sedang maka siswa tersebut jarang atau bahkan tidak merokok. Hal ini dikuatkan dari hasil wawancara dengan siswa yang merokok bahwa siswa yang melakukan perilaku merokok disebabkan karena siswa tidak percaya diri dan tidak dapat menghindar untuk mengikuti gaya serta ajakan teman-teman lain yang merokok sehingga siswa yang memiliki konformitas teman sebaya yang tinggi akan sangat bisa untuk melakukan perilaku merokok. Asertivitas diperlukan agar remaja dapat menyesuaikan diri, khususnya pada konformitas negatif. Dengan demikian menunjukkan bahwa konformitas teman sebaya dan asertivitas dapat mempengaruhi perilaku merokok pada siswa di SMP N 2 Sleman.

Besarnya sumbangan yang diberikan oleh konformitas teman sebaya terhadap perilaku merokok sebesar 22,1\%, sedangkan sumbangan yang diberikan oleh asertivitas terhadap perilaku merokok sebesar $16,5 \%$. Artinya, besarnya sumbangan yang diberikan oleh konformitas teman sebaya dan asertivitas terhadap perilaku merokok sebesar 38,6\%, sedangkan sisanya $61,4 \%$ dipengaruhi oleh faktor lain, seperti pola asuh orang tua, kebudayaan, dukungan sosial dan tingkat pendidikan.

\section{SIMPULAN}

Berdasarkan hasil penelitian, analisis, dan pengujian hipotesis dapat ditarik kesimpulan yaitu 1) siswa SMP N 2 Sleman memiliki tingkat konformitas sebaya kategori sedang, tingkat asertivitas kategori sedang, dan tingkat perilaku merokok kategori rendah 2) terdapat hubungan yang positif dan signifikan antara konformitas teman sebaya dengan perilaku merokok, 3) terdapat hubungan yang negatif dan signifikan antara asertivitas dengan perilaku merokok, 4) terdapat hubungan yang signifikan antara konformitas teman sebaya dan asertivitas dengan perilaku merokok, 5) sumbangan efektif konformitas teman sebaya dan asertivitas terhadap perilaku merokok sebesar 38,6\%.

Bagi siswa SMP N 2 Sleman diharapkan melakukan konformitas teman sebaya yang positif dan tidak melakukan konformitas negatif, serta perlunya ditingkatkan sikap asertif agar remaja dapat menyesuaikan diri, baik dalam konformitas positif maupun konformitas negatif dalam pergaulannya. Selain itu, diharapkan siswa dapat terus mempertahankan untuk tidak merokok atau bagi siswa perokok diharapkan dapat menurunkan dan menghilangkan kebiasaan merokok tersebut. Bagi konselor diharapkan selalu memberikan dukungan, memfasilitasi lingkungan yang mampu memberikan contoh yang baik untuk perkembangan para siswa, serta memberikan layanan bimbingan yang sesuai dengan keadaan dan kebutuhan siswa terkini. Bagi peneliti selanjutnya disarankan untuk lebih membatasi karakteristik subjek, misalnya dilihat dari jenis kelamin sehingga dapat menunjukkan perilaku merokok yang lebih spesifik kaitannya dengan konformitas teman 
sebaya dan asertivitas. Selain itu, peneliti menyarankan penelitian lebih memperluas ruang lingkup, misalnya dengan memperluas populasi, atau menambah variabel-variabel lain sebagai faktor yang dapat mempengaruhi perilaku merokok pada remaja, seperti: pola asuh orang tua, kebudayaan, dukungan sosial dan tingkat pendidikan. Hal ini dikarenakan faktorfaktor tersebut belum disinggung dalam penelitian ini serta agar hasil yang didapat lebih bervariasi dan beragam.

\section{DAFTAR PUSTAKA}

Anna, E. O. (2010). Gambaran Pengetahuan, Sikap dan Perilaku Pelajar di Salah Satu SMA di Banjarmasin Mengenai Masalah Merokok. (Skripsi). Universitas Kristen Maranatha.

Eka, R. dkk. (2008). Perkembangan Peserta Didik. Yogyakarta: UNY Press.

Dita, L. \& Benny H. (2007). Hubungan antara Konformitas dengan Perilaku Merokok pada Mahasiswi Universitas Islam Indonesia. (Skripsi). Yogyakarta: Universitas Islam Indonesia.

Hurlock, E. B. (1991). Psikologi Perkembangan: Suatu Pendekatan Sepanjang Rentang Kehidupan. (Alih Bahasa: Istiwidayanti). Jakarta: Erlangga.

Komalasari, D., \& Helmi, A. F. (2000). Faktor-Faktor Penyebab Perilaku Merokok pada Remaja. Jurnal Psikologi Universitas Gajah Mada. Yogyakarta: Universitas Gajah Mada.

Marvyn, G. H., \& Shryock, H. (2001). Kiat Keluarga Sehat: Mencapai Hidup Prima dan Bugar. (Alih Bahasa: Ruben Supit). Jakarta: Indonesia Publishing House.

McCool, J., Cameron, L., Petrie, K., \& Robinson, E. (2003). Smoking Behavior and Expectations among Auckland Adolescent. The New Zealand Medical Journal, hlm. 1-9.

Meizha, R. C. (2012). Hubungan antara Konformitas Teman Sebaya dan Konsep Diri dan Perilaku Merokok pada Remaja. Abstrak Hasil Penelitian. Surabaya: Universitas Airlangga.

Nurul, F. (2010). Hubungan Terpaan Iklan Produk Rokok di Televisi dan Tingkat Konformitas Kelompok Teman Sebaya terhadap Kecenderungan Perilaku Merokok. (Skripsi). Semarang: Universitas Diponegoro.

Pearl, Bryan, Herzog. (1990). Journal of Youth and Adolescence. Volume:19, hlm. 43-55. United States. 
162 Aryani \& Laras - Hubungan antara Konformitas ...

Rochadi R. K. (2004). Hubungan Konformitas dengan Perilaku Merokok pada Remaja Sekolah SMU Negeri di 5 Wilayah DKI Jakarta. Disertation Abstract. Jakarta: Universitas Indonesia.

Santrock, J. W. (2003). Adolecense: Perkembangan Remaja. (Alih Bahasa: Soedjarwo). Jakarta: Erlangga.

Sarwono, S. W. (1999). Psikologi Sosial. Jakarta: Balai Pustaka.

Shvoong.com. (2012). Fenomena Merokok di Kalangan Pelajar. Diakses dari http://id.shvoong.com/writing-and-speaking/presenting/2098788-fenomenamerokok-dikalangan-pelajar/\#ixzzlmgfLGPqG, pada tanggal 14 Desember 2012, Jam 19.10 WIB.

Yulita, M. (2011). Health Locus of Control Reliationship and Assertive Behavior in Smoker. (Skripsi). Universitas Gunadharma. 